$12-9867$

http://www.jfas.info

\title{
EVALUATING THE EFFECT OF FAMILY RELATIONS IN THE BOARD OF DIRECTORS ON PROFIT MANAGEMENT BY APPLYING "DECHOW AND DICHEV" AND "KOTHARI" MODELS
}

\author{
M. Fallah, F. Heirany*
}

Department of Accounting, Yazd Branch, Islamic Azad University, Yazd, Iran

Published online: 16 July 2016

\begin{abstract}
The main purpose of this research is to evaluate the effect of family control over the profit management in the listed companies on the Stock Exchange in Tehran. In this research, the profit management is considered as the dependent variable and the control of the company is considered as the independent variable. Dechow and Dichev and Kothari Models have been used to measure the profit management. In addition, a dummy variable is used to measure the company's control. The research population is the listed companies in Tehran Stock Exchange and the sample consisted of 32 family firms that were selected using systematic elimination method. The research is from 2007 to 2012. Research hypotheses have been testedusing correlation method between variables and multiple regression equations through panel data method. The results suggest that family relations have a significant impact on the Board of Directors on profit management using Dechow and Dichev, and Kothari Models.
\end{abstract}

Keywords: family firms, family control, family business, discretionary accruals, profit management practices.

Author Correspondence, e-mail: heirany@iauyazd.ac.ir doi: http://dx.doi.org/10.4314/jfas.v8i2s.37 


\section{INTRODUCTION}

Ownership structure is different (Hussaini, 1390). Ownership structure is classified into four classes: 1.Institutional ownership, 2.Corporate ownership, 3. Management ownership, 4.Foreign ownership. Management investors are family firms that the majority of ownership is possessed by a family or group family (Standard, 1390). In other words, family firms have been recognized as an organization that is managed and controlled by several family members (Zehir et al., 2011). Family members have ownership concentration and they are the member of the board of directors and management team (Cheng, 2014). Leadership and management of a company in itself are difficult and it becomes more difficult when the board members, shareholders, and business consultants want better control of the company. Control and monitoring the family-owned businesses is more difficult than companies whose owners are strange. In family businesses, both families and homeowners interested in monitoring and controlling or dominating. In family businesses, the lack of effective governance is the main cause of organizational problems (Farmer, 2011). Most studies related to family firms have been focused on the agency conflict framework (Change, 2014). Based on agency theory, the conflict of interests concerns the owners (shareholders) so that they assess the performance of managers to ensure the optimum allocation of resources by the management. Over time, it has been found that some management decisions may be a waste of resources and loss of owners' wealth. On the other hand, managers are always seeking to ensure the owners that their decision is in the interests of the owners in addition to maximize their benefits (AkbariGhoroghchi, 2011). Regarding family firms, family members are the manager and the owner of a part of the company stock. Therefore, these people are both the owner and the agency. No problem will be created in the relationship of the agency and the owner until the company be looked from this view. However, it should be noticed that in some companies, other people are the stockholder in addition to family members, but they have no any management positions. Therefore, it is possible that family members of the Board of Directors act as the detriment of other shareholders and increase their wealth in this way (NaderiNayeri, 2013). According to accounting theory, the main purpose of profit reporting is providing useful information for people who are most interested in the financial statements. Assuming that, management thinks 
of its own interests, managers may manipulate managers may manipulate, or in other words, manage the profit to gain the greatest benefits. Profit has an important role as an appropriate index in investors' decision-making. Given that, managers are able to give misleading information to the users by manipulating profit and profit management is a means to manipulate profits by manager, the ownership structures need to pay more attention and the provided information need to be analyzed (Mehrazin et al. 2013). Therefore, based on the mentioned cases, it is necessary to examine profit management in family firms. Finally, this research seeks to answer the question that whether the family control affects profit management practices.

\section{Theoretical Principles and research literature}

\section{Family firms}

Yang and Tsai (2008) mentioned at least ten percent of the shares ownership by family members as a condition of family firms. Chakrabarty (2009) defines family firms as a firm, in which a private person is as the controlling shareholder of the company or in other words, a private person has at least twenty percent of the shares of a particular company. A family firm is a firm whose shares are owned by a family and the family member are the Board of Directors or in the management and operational positions (International Finance Corporation of the World Bank, 2013).

\section{The life cycle of family firms}

Generally, family firms have three phases in their life cycle:

First generation: In this generation of family firms, one or more people are the owners and shareholders. These shareholders form both the board of directors and the management team. This leads to simplicity and ease of work, but the lack of distinction between ownership and management may make the work difficult for independent people and they prefer to leave the company.

Second generation: In this generation, there are usually several owners, but they all have a contribution rate. Less activeowners enter the Board or only participate in plenary sessions, but active shareholders managethe company. In this situation, there is often disagreement about business strategy. 
Third Generation: The third-generation family firms often are bigger and require professional management. The required consensus, competition, and ambition may not be found among family members; therefore, there is an urgent need to manage from outside the family. Managing the firm at this stage is very complicated and leads to conflict.

\section{The Board of Directors in family firms}

The Board of Directors is the central institution of many organizations, including family-oriented organizations. The structure and composition of the board of directors in family-oriented firms are different.In the first years of genesis, most of family organizations formthe Board of Directors in order to comply with legal requirements. The duties of this board, which are known as "The Board of Directors on paper" is mostly limited to approving financial affairs, dividing profit, and other executive methods that requires the approval of the Board of Directors. Their meetings are held twice a year according to legal requirements in very short time with quick decision-making. The composition of these boards consists of only family members and in some cases; a small number oftrusted senior managers are present.

\section{The role of The Board of Directors}

The main role of a well-functioningBoard of Directors is determining the company's overall strategy, monitoring the performance of managers and ensuing the establishment of appropriate firm governance, including overwhelming dominance of the environment, and the existence of sufficient transparency mechanism is adequate to protect the minority rights. The amount of time and effort for each field, which is allocated by the Board of Directors depend on the size and complexity of the family business. For example, a company with a few shareholders, simple business processes, efficient internal control and the level of participation of the owners needs the focus of the Board of Directors on long-term strategy and planning. Family business Board of Directors should bring value added to companies and avoid repeating what has already been done by other companies by the authorities. For example, the Board of Directors should lead the company's daily management and not directly involvein it, because it is primarily the duty of the executive management of the company. In addition, the Board of Directors has the freedom and resources to oversee and challenge the decisions and other activities by family members or the management (ibid, 2013). 


\section{The Foundation of Profit Management}

The main role of financial reporting is transferring the financial information to persons outside the organization in an appropriate and on time way. In doing so, the mangers have opportunities in the financial reporting to judge. The managers could make use of their knowledge about the financial activities to promote the efficacy of financial statements as a tool to transfer information to the shareholders and potential creditors. Notwithstanding this, if the managers intend to mislead the users of financial statements (inside or outside the organization) through using their power in the accounting selections in financial statements, profit management may occur (NaderiNiri, 2013). Hilly and Helen (1999) state that the profit management occurs only when the mangers make use of their subjective judgments in the financial reporting and manipulate the structure of transactions for the aim of changing the financial reporting. This aim is either to mislead some of the profit owners concerning the economic performance of the firm or to affect the results of transactions whose conclusions depend on achieving personal profit (Royai and Mohammadi, 2011).

\section{Control of family business and its impact on profit management}

Several members of a family who are linked ties of kinship or marriage and manage the family-owned businesses as owners, managers, or board members at the same time or over time in the Company are named family businesses (Lopez Deigado\&Dieguez Soto, 2015). According to Gersic et al. (1997), family businesses are mainly in the form of companies in the world. A dominant feature of these companies is that the control is concentrated in the hands of a family group (Almeida- Santos et al, 2013). Management usually consists of family members and the Board often has outsider individuals (Abdul-Manaf et al., 2013). According to Hu and Yang (2001) when the Board of Directors is considered as the "under the control of the family" that at least two or more family members to be appointed as controller (Jagg et al., 2009). Involving family members in management allows them to have a wide range of information on company operations. As a result, family members can be able to have flexible, timely, and effective decisions. Since family members control the company's operations, so the company is dominant. According to the entrenchment effect, the owner may engage in transactions that involve their personal interests. Since the owners have control over the company's financial 
reports, they are able to manage their accounting data for their personal purposes. Since, they are concerned with their families' reputation, so they provide high quality profits to protect the family reputation (Abdul-Manaf et al., 2013). Considering the aforementioned principles, to achieve the main objective of the study, the following hypotheses have been proposed and tested:

H1: family relations have a significant impact in the Board of Directors on profit management (Dechow and Dichev model).

$\mathrm{H} 2$ : family relations have a significant impact in the Board of Directors on profit management (Kothari model).

\section{A Review of the Previous Research}

Wang et al., (2010) conducted research entitled "Profit Management via Selling the Properties". The objective of this study was to examine the relation between profit management, selling the long-term properties and investing in firms listed in Taiwan. This shows that selling the properties is a way to manipulate the reported profits for 12484 firms and for the period of 1984 to 2006 . The obtained results showed that around 54-57 percent of the companies in Taiwan with little loss manipulated the reported profits to show that the profit is positive. Swang et al. (2013) in a study investigated "the Relation between the Profit Management and Embezzlement of Assents". The data for this study were gathered from the 173 firms which were proven to have conducted embezzlement between 2006 and 2010. To examine the hypotheses, the linear and logistic regressions were utilized. The reported results showed that there was a significant and positive association between embezzlements of the assets anddiscretionary accruals. The accrual accounting basis not only provides cues to discover the embezzlement of the profits, but also plays an important role in decreasing information asymmetry. Chi et al, (2015) carried out research with the aim of investigating the relation between family firms and profit management with the consideration of the effects of undependability of the board of directors. In this study, 379 firms with more than seven years of technology were chosen in Taiwan. The findings illustrated that there is a positive association between the family firms and profit management. In addition, the researcher also found out that: 1) the ratio of independent directors is associated with the decrease of profit management in 
family firms. 2) the duality of obligations of the directors is associated with the increase of the profit management in the family firms. The independency of the board of directors for a new generating market to reduce the profit management behaviour from the family firms is important.

Habash and Al-Ghamadi (2015) in an article examined the motivations of the profit management in general firms in Saudi Arabia. In doing so, the researcher employed interviews and questionnaires. The results indicated that increasing the amount of rewards, an acceptable report of profit, averting losses, obtaining the bank loans, and increasing the price of the share are among the motivations for Saudi directors to exercise profit management. MehrAzi et al. (2013) did a study entitled "Familial Ownership, Non-family Firms and Profit Management". In this study, after analyzing all the firms accepted in the stock exchange, 31 firms found to be family based. Then, they were separated to different industries. Next, following the same number of firms and the same industries, other firms were randomly chosen and were categorized as non-family firms. The modified model of Jones was taken into consideration for examining the research hypotheses as well as calculating the profit management. The overall results showed that there was a significant relation between the structure of the firm ownership and profit management and the non-family firms exercise more profit management.

\section{METHOD}

\section{Research Design}

Methodologically speaking, this study is applied. The research is also naturalistic as it examines the relation between the variables in their natural forms and without any manipulation. Thus, it puts the study in the category of correctional study.

\section{Population and Sample}

To gather information related to the literature, a library research approach was used. The population of this study involves all the firms accepted in Tehran Stock Exchange and to select the samples a systematic sampling technique was employed. The sample of the study, by considering, the said limitations and the variable of control of the firm (through examining the 
board of directors and the board of supervisors), 32 firms were selected from the firms accepted in Tehran Stock Exchange.

\section{Data Collection}

To collect the data, the RahavardNovin and the official website of Tehran Stock Exchanges were taken into account. To computerize the data, the Eviews software program was employed and to test the hypotheses of the study, the correlation and regression analyses through the Panel Data were used. In what follows, the research models and variables are introduced.

\section{Evaluating the Variables}

\section{The Model Determining the Relation between the Discretionary Accruals (Profit}

\section{Management) and Firm Control}

In the current study, the multiple regression, which is the main model of study, was employed to examine the effects of family control on profit management actions.

Model (1)

$\mathrm{ACD}_{i, \mathrm{t}}=\alpha_{\mathrm{i}}+\alpha_{1} \mathrm{CCO}_{\mathrm{i}, \mathrm{t}}+\alpha_{2} \mathrm{SIZE}_{\mathrm{i}, \mathrm{t}}+\alpha_{3} \mathrm{LEV}_{\mathrm{i}, \mathrm{t}}+\alpha_{4} \mathrm{ROE}_{\mathrm{i}, \mathrm{t}}+\alpha_{5} \mathrm{ROA}_{\mathrm{i}, \mathrm{t}}-\alpha_{6} \mathrm{AGE}_{\mathrm{i}, \mathrm{t}}+\varepsilon_{\mathrm{i}, \mathrm{t}}$

In that:

$\alpha_{1}, \ldots, \alpha_{6}:$ The estimated coefficient of the model

$\varepsilon_{\mathrm{i}, \mathrm{t}}$ : estimating the error of the model

In Table 1, the variables of the model are presented:

Table 1: Introducing the Variables in the Model

\begin{tabular}{|c|c|c|c|}
\hline $\begin{array}{c}\text { The } \\
\text { variable } \\
\text { symbol }\end{array}$ & $\begin{array}{c}\text { The type of } \\
\text { variable }\end{array}$ & The evaluation method & Reference \\
\hline ACD & Dependent & $\begin{array}{r}\text { Managing the profit with manipulating } \\
\text { discretionary accruals are evaluated via } \\
\text { the modified model of Jones and Model }\end{array}$ & $\begin{array}{r}\text { ShafaKhibari, 1390) } \\
\text { (Almeida- Santos } \\
\text { (Etemadi and }\end{array}$ \\
\hline CCO & Independent & $\begin{array}{r}\text { Family firm control is conducted through } \\
\text { the investigation of the board of }\end{array}$ & $\begin{array}{r}\text { (Almeida- Santos } \\
\text { etal,2013) }\end{array}$ \\
\hline
\end{tabular}




\begin{tabular}{|c|c|c|c|}
\hline & & $\begin{array}{l}\text { directors and board of supervisors. If the } \\
\text { last name of the two are the same, this } \\
\text { firm is under the control of the family } \\
\text { which is evaluated by the designed } \\
\text { variable. If the firm is under the control } \\
\text { of family, number } 1 \text { is considered } \\
\text { otherwise number } 0 \text { is given. }\end{array}$ & \\
\hline SIZE & \multirow{5}{*}{ Control } & $\begin{array}{l}\text { The size of the firm is evaluated by the } \\
\text { natural logarithm of the whole assets of } \\
\text { the firm } \mathrm{i} \text { in the year of } \mathrm{t} \text {. }\end{array}$ & $\begin{array}{c}\text { (RahnamyRoudposhti } \\
\text { et al., 2012) }\end{array}$ \\
\hline LEV & & $\begin{array}{l}\text { Financial leverage is evaluated based on } \\
\text { the ratio of the whole debts to the } \\
\text { whole assets of the firm in the year of } t \text {. }\end{array}$ & (Mahdavi et al., 2013) \\
\hline ROE & & $\begin{array}{l}\text { The rate of return of shareholders' wage } \\
\text { is obtained from the division of net profit } \\
\text { to shareholders' wage of firm i in the } \\
\text { year of } t \text {. }\end{array}$ & $\begin{array}{c}\text { (RahnamyRoudposhti } \\
\text { et al., 2012) }\end{array}$ \\
\hline ROA & & $\begin{array}{l}\text { Return on assets is obtained from the } \\
\text { ratio of the net profit to the whole assets } \\
\text { of firm i in the year } t \text {. }\end{array}$ & $\begin{array}{l}\text { (Nayebzadeh et al., } \\
\text { 2011) }\end{array}$ \\
\hline AGE & & $\begin{array}{l}\text { The life span of the firm is evaluated } \\
\text { based on the difference between the } \\
\text { year of } t \text { and year of establishment. }\end{array}$ & $\begin{array}{l}\text { (Karami and Omrani, } \\
\text { 2010). }\end{array}$ \\
\hline
\end{tabular}

\section{Dechow and Dichev model}

Using Dechow and Dichev model (2002), working capitalregression ofaccruals is calculated for past, present, and future cash flows in addition to changes in revenue and gross value of property, machinery, and equipment. Accruals quality is the standardized residuals of this regression. 
Model (2)

Accruals $=\alpha+\beta_{1} * \mathrm{CF}_{\mathrm{i}, \mathrm{t}-1}+\beta_{2} * \mathrm{CF}_{\mathrm{i}, \mathrm{t}}+\beta_{3} * \mathrm{CF}_{\mathrm{i}, \mathrm{t}+1}$

Model (3)

$$
\text { Accruals }=\left(\Delta \mathrm{CA}_{\mathrm{i}, \mathrm{t}}-\Delta \operatorname{Cash}_{\mathrm{i}, \mathrm{t}}\right)-\left(\Delta \mathrm{CL}_{\mathrm{i}, \mathrm{t}}-\Delta \mathrm{STD}_{\mathrm{i}, \mathrm{t}}\right)-\mathrm{Dep}_{\mathrm{i}, \mathrm{t}}
$$

$\Delta \mathrm{CA}_{\mathrm{i}, \mathrm{t}}=$ Change in current assets

$\Delta$ Cash $_{\mathrm{i}, \mathrm{t}}=$ Change in cash/cash equivalents

$\Delta \mathrm{CL}_{\mathrm{i}, \mathrm{t}}=$ Change in current debt

$\Delta \mathrm{STD}_{\mathrm{i}, \mathrm{t}}=$ Change in short-term debt

Dep $_{\mathrm{i}, \mathrm{t}}=$ Amortization expense of fixed and intangible assets in year $\mathrm{t}$.

Cash Flows $=$ cash flows

$\Delta$ Revenue $=$ Change in revenue

$\mathrm{PPE}_{\mathrm{i}, \mathrm{t}}=$ The gross value of property, machinery, and equipment.

\section{Kothari model}

Kothari et al., (2005) modifiedJones model by adding the variable of return on assets (ROA) as a control variable. The model is as follows:

Model (4) $\mathrm{TACC}_{\mathrm{i}, \mathrm{t}}=\alpha_{1}\left(\frac{1}{\mathrm{AT}_{\mathrm{i}, \mathrm{t}-1}}\right)+\alpha_{2}\left(\frac{\Delta \mathrm{Sale}_{\mathrm{i}, \mathrm{t}}}{\mathrm{AT}_{\mathrm{i}, \mathrm{t}-1}}\right)+\alpha_{3}\left(\frac{\mathrm{PPE}_{\mathrm{i}, \mathrm{t}}}{\mathrm{AT}_{\mathrm{i}, \mathrm{t}-1}}\right)+\alpha_{4} \mathrm{ROA}_{\mathrm{i}, \mathrm{t}-1}+\varepsilon_{\mathrm{i}, \mathrm{t}}$

TACC $_{\mathrm{i}, \mathrm{t}}=$ Total accruals of company $\mathrm{i}$ in year $\mathrm{t}$.

$\Delta$ sale $_{\mathrm{i}, \mathrm{t}}=$ Sale changes of company $\mathrm{i}$ in year $\mathrm{t}$.

$\mathrm{PPE}_{\mathrm{i}, \mathrm{t}}=$ Net property, machinery, and equipment $\mathrm{i}$ in year $\mathrm{t}$.

$\mathrm{ROA}_{\mathrm{i}, \mathrm{t}-1}=$ Return on assets (net income divided by average total assets) for $\mathrm{i}$ in year $\mathrm{t}-1$.

$\mathrm{AT}_{\mathrm{i}, \mathrm{t}-1}=$ Total assets of company $\mathrm{i}$ in year $\mathrm{t}-1$.

Model (5) $\mathrm{TACC}_{\mathrm{i}, \mathrm{t}}=\left(\Delta \mathrm{CA}_{\mathrm{i}, \mathrm{t}}-\Delta \mathrm{Cash}_{\mathrm{i}, \mathrm{t}}-\Delta \mathrm{CL}_{\mathrm{i}, \mathrm{t}}+\Delta \mathrm{STD}_{\mathrm{i}, \mathrm{t}}-\mathrm{Dep}_{\mathrm{i}, \mathrm{t}}\right) / \operatorname{laggedAT}$

$\Delta \mathrm{CA}_{\mathrm{i}, \mathrm{t}}=$ Change in current assets from year $\mathrm{t}-1$ to the year $\mathrm{t}$.

$\Delta$ Cash $_{\mathrm{i}, \mathrm{t}}=$ Change in cash and cash equivalents of year $\mathrm{t}-1$ to year $\mathrm{t}$.

$\Delta \mathrm{CL}_{\mathrm{i}, \mathrm{t}}=$ Change in current debt of year $\mathrm{t}-1$ to year $\mathrm{t}$.

$\Delta \mathrm{STD}_{\mathrm{i}, \mathrm{t}}=$ Change in current portion of long-term debt from year t-1 to year $\mathrm{t}$. 
$\operatorname{Dep}_{\mathrm{i}, \mathrm{t}}=$ Amortization expense of fixed and intangible assets in year $\mathrm{t}$.

laggedAT $=$ Total assets of company $\mathrm{i}$ in year $\mathrm{t}-1$.

To calculate the non-discretionary accruals, themodified Jones model is acted by adding ROA as follows:

Model (6) NDACC $_{i, t}=\beta_{1}\left(\frac{1}{\mathrm{AT}_{\mathrm{i}, \mathrm{t}-1}}\right)+\beta_{2}\left(\frac{\Delta \mathrm{Sale}_{i, \mathrm{t}}-\Delta \mathrm{REC}}{\mathrm{A} \mathrm{T}_{\mathrm{i}, \mathrm{t}} \mathrm{t}-1}\right)+\beta_{3}\left(\frac{\mathrm{PPE}_{\mathrm{i}, \mathrm{t}}}{\mathrm{AT}_{\mathrm{i}, \mathrm{t}-1}}\right)+\beta_{4} \mathrm{ROA}_{\mathrm{i}, \mathrm{t}-1}+\varepsilon_{\mathrm{i}, \mathrm{t}}$ $\Delta \mathrm{REC}_{\mathrm{i}, \mathrm{t}}=$ Change in net accounts and commercial receivables of company $\mathrm{i}$ in the year $\mathrm{t}$.

And finally, to obtain discretionary accruals $\left(\mathrm{DACC}_{\mathrm{i}, \mathrm{t}}\right)$, total accruals $\left(\mathrm{TACC}_{\mathrm{i}, \mathrm{t}}\right)$ is deducted to non-discretionary accruals $\left(\mathrm{NDACC}_{\mathrm{i}, \mathrm{t}}\right)$ as follows:

Model (7) DACC $_{i, t}=$ TACC $_{i, t}-$ NDACC $_{i, t}$

\section{RESEARCH FINDINGS}

\section{Hypotheses Analysis}

\section{Hypothesis 1 (H1)}

In order to test the hypothesis, a pre-test is needed to be conducted. In this paper, the Chow test is used to determine the cross fixed and time constant effects that its scale should be smaller than 0.05 . Since, in this paper, the probability is smaller than 0.05 , the cross fixed effects are confirmed and the time constant effects are rejected. In order to determine the random-effects and fixed-effects, Hausman test is used. If the probability is smaller than 0.05 , the random-effects are rejected and the fixed-effects are confirmed. According to the conducted tests, the fixed effects are confirmed. The results of hypothesis testing in this method are presented in Table 2.

Table 2. Analysis of the first hypothesis (the calculation of profit management by using Dechow and Dichev model)

\begin{tabular}{|c|c|}
\hline $\begin{array}{c}\text { Adjusted coefficient } \\
\text { of determination }\end{array}$ & 0.524638 \\
\hline F statistic & 3.833725 \\
\hline The probability (Prob) & 0 \\
\hline
\end{tabular}




\begin{tabular}{|c|c|c|c|c|c|}
\hline \multirow{2}{*}{$\begin{array}{l}\text { Durbin-Watson statis } \\
\text { tic } \\
\text { Explanatory variable }\end{array}$} & \multicolumn{5}{|c|}{1.984883} \\
\hline & $\begin{array}{r}\text { Co } \\
\text { efficie } \\
n t\end{array}$ & $\begin{array}{l}\text { Standard } \\
\text { deviation }\end{array}$ & $\begin{array}{l}\mathrm{T}-\mathrm{s} \\
\text { tatisti } \\
\mathrm{C}\end{array}$ & $\begin{array}{l}\text { Po } \\
\text { ssibili } \\
\text { ty }\end{array}$ & $\begin{array}{l}\text { Confide } \\
\text { nce level }\end{array}$ \\
\hline $\mathrm{CCO}$ & $\begin{array}{r}0.7 \\
39879\end{array}$ & $8^{0 / 20200}$ & $\begin{array}{r}3 / \\
6626 \\
28\end{array}$ & $\begin{array}{r}0 / \\
0005\end{array}$ & $99 \%$ \\
\hline AGE & $\begin{array}{r}-0 / \\
41578\end{array}$ & $\begin{array}{c}0 / 08092 \\
7\end{array}$ & $\begin{array}{l}-5 / \\
1376 \\
9\end{array}$ & 0 & $99 \%$ \\
\hline LEV & $\begin{array}{r}2 / 1 \\
11652\end{array}$ & $\begin{array}{c}0 / 32820 \\
9\end{array}$ & $\begin{array}{r}6 / \\
4338 \\
59\end{array}$ & 0 & $99 \%$ \\
\hline ROA & $\begin{array}{r}0 / 0 \\
06296\end{array}$ & $\begin{array}{c}0 / 01241 \\
8\end{array}$ & $\begin{array}{r}0 / \\
5070 \\
28\end{array}$ & $\begin{array}{r}0 / \\
6141\end{array}$ & $\begin{array}{l}\text { Without } \\
\text { meaning }\end{array}$ \\
\hline ROE & $\begin{array}{r}5 / 7 \\
9 E-05\end{array}$ & $\begin{array}{c}0 / 00030 \\
7\end{array}$ & $\begin{array}{r}0 / \\
1889 \\
19\end{array}$ & $\begin{array}{r}0 / \\
8508\end{array}$ & $\begin{array}{l}\text { Without } \\
\text { meaning }\end{array}$ \\
\hline SIZE & $\begin{array}{r}2 / 5 \\
2 E+00\end{array}$ & $\begin{array}{c}1 / 12081 \\
1\end{array}$ & $\begin{array}{r}2 / \\
2484 \\
46\end{array}$ & $\begin{array}{r}0 / \\
0284\end{array}$ & $95 \%$ \\
\hline C & $\begin{array}{r}-0 / \\
0322\end{array}$ & $\begin{array}{c}5 / 65194 \\
7\end{array}$ & $\begin{array}{r}-0 / \\
0057\end{array}$ & $\begin{array}{r}0 / \\
9955\end{array}$ & $\begin{array}{l}\text { Without } \\
\text { meaning }\end{array}$ \\
\hline
\end{tabular}

According to F-statistic and its probability, it can be concluded that the regression equation is significant at $99 \%$ confidence level. The results of the Durbin - Watson statistic (the lack of correlation of error terms) for the model indicate the relative independence of the data. The 
adjusted coefficient of determination in the model expresses the degree of relevance of independent variables and the dependent variable (profit management). According to Table 2, the adjusted coefficient of determination is 0.52 . Therefore, on average, 52 percent of dependent variables are explained by this model. According to the test results of the model related to variables, the company control variable (CCO) is likely less than 0.01 . Therefore, this variable is significant at a confidence level of $99 \%$ in the model. In addition, the covariates of company age (AGE) and financial leverage (LEV) have a probability of less than 0.01 and the variable of company size (SIZE) is likely less than 0.05 . Thus, these variables aresignificant at a confidence level of 99\% and 95\%, respectively. However, return on equity (ROE) and return on assets (ROA) variables have been more likely than 0.05 and they are not significant in the model at $95 \%$ confidence level. Considering the significance, the company control variable (CCO), which is the main variable of the model in confirming or rejecting the hypothesis, it can be claimed that the family relations are effective in the Board of Directors on profit management (Dechow and Dichev model). Therefore, according to the results, the first hypothesis is confirmed.

\section{Hypothesis 2 (H2)}

The results of hypothesis testing in this method are presented in Table 3.

Table 3. The analysis of the second hypothesis (the calculation of profit management by using Kothari model)

\begin{tabular}{|c|c|c|c|c|c|}
\hline $\begin{array}{l}\text { Adjusted coefficient } \\
\text { of determination }\end{array}$ & \multicolumn{5}{|c|}{0.770105} \\
\hline F statistic & \multicolumn{5}{|c|}{9.600845} \\
\hline The probability (Prob) & \multicolumn{5}{|c|}{0} \\
\hline $\begin{array}{c}\text { Durbin-Watson statis } \\
\text { tic }\end{array}$ & \multicolumn{5}{|c|}{1.967818} \\
\hline Explanatory variable & $\begin{array}{l}\text { Coe } \\
\text { fficien } \\
t\end{array}$ & $\begin{array}{l}\text { Standard } \\
\text { deviation }\end{array}$ & $\begin{array}{l}\text { T-s } \\
\text { tatisti } \\
\text { C }\end{array}$ & $\begin{array}{l}\text { Po } \\
\text { ssibili } \\
\text { ty }\end{array}$ & $\begin{array}{l}\text { Confide } \\
\text { nce level }\end{array}$ \\
\hline
\end{tabular}




\begin{tabular}{|c|c|c|c|c|c|}
\hline $\mathrm{CCO}$ & $\begin{array}{r}0 / 0 \\
50757\end{array}$ & $0 / 02382$ & $\begin{array}{r}2 / \\
9308 \\
81\end{array}$ & $\begin{array}{r}0 / \\
0097\end{array}$ & $\% 99$ \\
\hline AGE & $\begin{array}{r}-0 / \\
01427\end{array}$ & $\begin{array}{l}\text { 0/00637 } \\
7\end{array}$ & $\begin{array}{l}-2 / \\
2371 \\
9\end{array}$ & $\begin{array}{r}0 / \\
0291\end{array}$ & \%99 \\
\hline LEV & $\begin{array}{r}-0 / \\
32724\end{array}$ & $\begin{array}{c}0 / 01520 \\
5\end{array}$ & $\begin{array}{l}-2 \\
1 / 521 \\
2\end{array}$ & 0 & $\% 99$ \\
\hline ROA & $\begin{array}{r}0 / 0 \\
01143\end{array}$ & $\begin{array}{c}0 / 00034 \\
8\end{array}$ & $\begin{array}{r}3 / \\
2847 \\
02\end{array}$ & $\begin{array}{r}0 / \\
0017\end{array}$ & $\% 99$ \\
\hline ROE & $\begin{array}{r}-0 / \\
00011\end{array}$ & 5/20E-05 & $\begin{array}{l}-2 / \\
1394 \\
3\end{array}$ & $\begin{array}{r}0 / \\
0366\end{array}$ & $\% 95$ \\
\hline SIZE & $\begin{array}{r}-0 / \\
20071\end{array}$ & $\begin{array}{c}0 / 05749 \\
9\end{array}$ & $\begin{array}{l}-3 / \\
4906 \\
9\end{array}$ & $\begin{array}{r}0 / \\
0009\end{array}$ & $\% 99$ \\
\hline C & $\begin{array}{r}1 / 8 \\
37024\end{array}$ & $\begin{array}{c}0 / 18934 \\
9\end{array}$ & $\begin{array}{r}9 / \\
7017 \\
7\end{array}$ & 0 & $\% 99$ \\
\hline
\end{tabular}

According to F-statistic and its probability, it can be concluded that the regression equation is significant at $99 \%$ confidence level. The results of the Durbin - Watson statistic (the lack of correlation of error terms) for the model indicate the relative independence of the data. The adjusted coefficient of determination in the model expresses the degree of relevance of independent variables and the dependent variable (profit management). According to Table 3, the adjusted coefficient of determination is 0.77 . Therefore, on average, 77 percent of dependent variables are explained by this model. According to the test results of the model 
related to variables, the company control variable (CCO) is likely less than 0.01 . Therefore, this variable is significant at a confidence level of $99 \%$ in the model. In addition, the covariates of the return on assets (ROA), financial leverage (LEV) and the company size (SIZE) have a probability of less than 0.01 and the variable of company age (AGE) is likely less than 0.05 . Thus, these variables aresignificant at a confidence level of $99 \%$ and $95 \%$, respectively. Considering the significance, the company control variable (CCO), which is the main variable of the model in confirming or rejecting the hypothesis, it can be claimed that the family relations are effective in the Board of Directors on profit management (Kothari model). Therefore, according to the results, the second hypothesis is confirmed.

\section{Discussion and Conclusion:}

The results of the first hypothesis showed that family relations are effective in the Board of Directors on profit management (Dechow and Dichev model). In Dechow and Dichev model, there is a direct relationship between cash flow and accruals in the current period. Since, the cash flows reflect that continuous income and productive operation is important for all participants, including shareholders, creditors, management, etc. This model has been created with this assumption that the occurring time of incomes and costs in the company is often different from the time of receipt and payment of cash. Accruals are reported as a result of this difference. Accounting system provides temporary modifications that alter the cash flows over time through accruals.In this case, accruals items act as a tool that misleads the users of the financial statements. In other words, these items can also affect cash flow because of access management, which leads to wrong decisions of the users. For example, creditors are mistaken for continued accreditation. Therefore, this issue gives the managers of family firms the opportunity to act to their interest and to the detriment of other shareholders. The results of this hypothesis are inconsistent with the research results of Khajavi et al. (2013). The second hypothesis results showed that family relations are effective in the Board of Directors on profit management (Kothari model). Kothari et al. adjusted the Jones model by adding the variable of return on assets that one of the profitability criteria is the return on assets rate. In fact, return on assets is a basic criterion to assess management performance. Performance assessment shows 
the amount of organizational success in achieving the goals. If these company managers can maximize the profit, then they have a suitable performance by achieving the company aims. Managers manage the reported profits according to the different goals and incentives such as impact on stock prices, maximizing their utility and welfare. Since, family members control theoperations in family firms and dominant it; they control the financial reports. Therefore, they manage the profit to achieve their goals and showing the good picture of companyprofitability. The results of this hypothesis are similar to the results of Jaggi et al. (2009).

The market decision makers and potential shareholders are recommended to consider the impact of family ownership on the information quality in reviewing the financial transparency of the studied companies. In addition, family firms managers are recommended to avoid applying the profit managementmeasures because this issue is perceived by the market in the long term and it will lead to negative results for the company. In order to efficient use of the research results and to clarify the impact of family control over the actions of profit management, it is proposed to investigate the effect of family control issues, the independence of the Board of Directors and profit management in family firms, the effect of family control over the quality of financial reporting in family firms, the effect of corporate governance and profit management in family and nonfamily firms. The future researches are recommended to test this study with different statistical population and for more years to increase the external validity of the research not only in the Tehran Stock Exchange, but also on other stock exchanges of the world, and provide moreand deeper information in this field. In addition, comparative studies between family and nonfamily firms in Tehran Stock Exchange and other stock exchanges in the world are recommended.

\section{REFERENCES}

[1] Abdul-Manaf, Kamarul Bahrain.Amran, Noor Afza and Che-Ahmad, Ayoib. Financial reporting quality of malaysian family firms. South East Asia Journal of Contemporary Business, Economics and Law, 2013, 3: 1-5. 
[2] AkbariGhoroghchi, Jalal, 2011, evaluating the performance and capital structure of family and nonfamily firms listed in the Tehran Stock Exchange, MS Thesis, Faculty of Economics, Management of Social Sciences, Shiraz University.

[3] Almeida - Santos, Paulo Sergio. Dani, AndreiaCarpes. Machado, Debora Gomes and Krespi, Nayane Thais. Influenc of family control in the practice of earnings management.the Journal of the Iberoamerican Academy of Management , 2013, 11(1): 77 - 99.

[4] Asta, Sohrab, investigating the relationship between ownership structure and profit management, financial accounting research, Issue II, serial number 8, Summer 2011, 106-93.

[5] Chakrabarty, Subrata. The in fluenco of national culture and institutional voids on family ownership of large firms: a country level empirical study. Journal of International Management, 2009, 15: $32-45$.

[6] Chang, Jui Chin and Sun, HeuyLian. Crossed - listed foreign firms earnings informativeness, earnings management and disclosures of corporate gonernance in formation under sox.the International Journal of Accounting , 2009, 44: 1 - 32.

[7] Cheng, Qian. Family firm research - a review.China Journal of Accounting Research, 2014, 7: $149-163$.

[8] Chi, Ching Wen. Hung, Ken. Cheng, Hui Wen and Yu, Ching Yi. Family firms and earnings management in taiwan: influence of corporate governance. International Review of Economics a Finance, 2015, 36, 88-98.

[9] Habbash,Muryaand Alghamdi,Salim. The perception of earnings management motivations in Saudi public firms. Journal of Accounting in Emerging Economies . 2015, 5: 122 - 147.

[10] Hosseini, Seyed Ali, 2011, the competitive evaluating the effect of ownership structure on the value of companies listed in Tehran Stock Exchange between different industries, master's thesis, Faculty of Humanities, Islamic Azad University of Shiraz.

[11] International Finance Corporation of the World Bank, 2013, corporate governance in family firms, translated by Ali Babaei, First Edition, Tehran, publisher of Gandoman.

[12] Jaggi,Bikki. Leung, Sidney and Gul, Ferdinand. Family control, board independence and earnings management: evidence based on hongkong firms. J. Account. Public Policy. 2009,28: $281-300$. 
[13] Karami, Gholamreza and Omrani, Hamed, the impact of the company's life cycle and conservatism on the value of the company, accounting and auditing Reviews, Issue 59, Spring $1389,96-79$.

[14] KhodaeiVeleZaghard, Mohammad and Yahyaei, Monireh, investigating the relationship between the quality of financial reporting and efficiency of investment in the Tehran Stock Exchange, Journal of Management Accounting, third, fifth edition, Summer 2010, 15-1.

[15] Lo pez-Delgado, P and Die guez-Soto, J. Lone founders, types of private family businesses and firm performance.Journal of Family Business Strategy, 2015: 1 - 13.

[16] Mahdavi, GholamHossein, Hosseini, SeyedMojtaba and Raeisi, Zohreh, the impact of corporate governance features on the estimated profit quality by listed companies in Tehran Stock Exchange, Journal of Management Accounting Research, Issue XVI, spring 2013, 60-43. [17] Mehrazin, Alireza, Qobedyan, Bashir, Foroutan, Omid and Taghipour, Mohammad, family and nonfamily ownership in companies and profit management, Quarterly of Audit Knowledge, 52, autumn 2013, 171-153.

[18] Nayebzadeh, Shahnaz, Moeinadin, Mahmoud and Qaysari, Zahra, comparative study of the relationship of extended market orientation (EMO) with Adjusted Economic Value Added (REVA), and return on assets (ROA) in manufacturing firms, Journal of Marketing Management, Issue 12, Autumn 2011, 133-113.

[19] NayeriNaderi, Nader, 2013, the type of company ownership, profit management, and audit quality, master thesis, Islamic Azad University, Science and Research of Yazd.

[20] RahnamayRoodposhti, Fereydoon and Salehi, Allah Karam, 2010, financial and accounting theories, including theories, hypotheses, models, techniques and tools, first printing, Tehran, Islamic Azad University of Tehran.

[21] RahnamayRoodposhti, Fereydoon, Heybati, Farshad, Talebnia, Ghodratollah and NabaviChashmi, Seyed Ali, providing a pattern to measure the corporate governance mechanisms in Tehran Stock Exchange on Earnings Management, Journal of Management Accounting Research, Issue XII, spring 2012, 100-79.

[22] Royaei, Ramazan Ali and Mohammadi, Mahdi, 2011, ethics and professionalism in accounting, first printing, Tehran, culture Library. 
[23] Song, Dan-Bee. Lee, Ho-Young and Cho, Eun-Jung. The association between earnings management and asset misappropriation. Managerial Auditing Journal , 2013, 28: $542-567$.

[24] Wang , Chuan-San. Tung , Samuel. Chen-Chang , Lin.Lan-Fen , Wang and Ching-Hui , Lai. Earnings management using asset sales: interesting issues for further study under unique institutional settings. International Journal of Accounting \& Information Management, 2010, 18: $237-251$.

[25] Young, Chaur-Shiuh and Tsai, Liu-Ching. The sensitivity of compensation to social capital: family $\mathrm{ceo}_{\mathrm{s}}$ vs. nonfamily $\mathrm{ceo}_{\mathrm{s}}$ in the family business groups. Journal of Business Research , 2008, 61: $363-374$.

[26] Zarei, Mohammad Reza, 2011, evaluating the importance of factors affecting the transfer of family businesses to the next generation from the perspective of their owners- case study: industrial companies of Alborz Province, Master Thesis, Ministry of Science, Research and Technology, Science and Culture.

[27] Zehir,Cemal. Altindag, Erkut and AcarA.Zafer. The effects of relationship orientation through innovation orientation on firm performance: an empirical study on turkish family-owned firms. Procedia Social and Behavioral Sciences . 2011, 24: 896 - 908.

\section{How to cite this article:}

Fallah M, Heirany F. Evaluating the effect of family relations in the board of directors on profit management by applying "dechow and dichev" and "kothari" models. J. Fundam. Appl. Sci., 2016, 8(2S), 1344-1362. 